\title{
PENGEMBANGAN MODUL PEMBELAJARAN BERBASIS MASALAH PADA MATERI LITOSFER UNTUK MENINGKATKAN KETERAMPILAN BERPIKIR KRITIS SISWA SMP
}

\author{
Dewi Rosnanda ${ }^{1}$, Sarwanto $^{2}$, Nonoh Siti Aminah ${ }^{3}$ \\ ${ }^{1}$ Program Studi Magister Pendidikan Sains FKIP Universitas Sebelas Maret \\ Surakarta, 57126, Indonesia \\ dewi_rosnanda@student.uns.ac.id. \\ ${ }^{2}$ Program Studi Magister Pendidikan Sains FKIP Universitas Sebelas Maret \\ Surakarta, 57126, Indonesia \\ sarwanto@staff.fkip.uns.ac.id \\ ${ }^{3}$ Program Studi Magister Pendidikan Sains FKIP Universitas Sebelas Maret \\ Surakarta, 57126, Indonesia \\ nonoh_nst@staff.uns.ac.id
}

\begin{abstract}
Abstrak
Masalah utama dalam pembelajaran IPA adalah pelaksanaan pembelajaran belum maksimal, akibatnya daya serap peserta didik rendah. Tujuan penelitian ini untuk: 1) mengembangkan modul pembelajaran dengan karakteristik pembelajaran berbasis masalah untuk meningkatkan keterampilan berpikir kritis siswa SMP pada materi litosfer, 2) mengetahui kelayakan modul pembelajaran berbasis masalah pada materi litosfer yang dikembangkan, 3) mengetahui implementasi modul pembelajaran berbasis masalah untuk meningkatkan keterampilan berpikir kritis siswa hasil pengembangan di SMP Nawa Kartika Wonogiri. Metode penelitian dan pengembangan yang digunakan Research and Development (R\&D). Model penelitian dan pengembangan menggunakan model penelitian 4D Thiagarajan dengan langkah: (1) tahap pendefinisian (define), (2) tahap perancangan (design), (3) tahap pengembangan (develop), (4) tahap penyebaran (dessiminate). Pengembangan modul ini dinilai berdasarkan kelayakan isi, penyajian, bahasa, dan kegrafikan, modul kemudian diujicobakan pada 15 siswa. Setelah direvisi, modul diujicobakan pada kelas IX.B. Modul pembelajaran ini berbasis masalah, dimana tahapan-tahapannya berupa orientasi pada situasi masalah, merumuskan hipotesis, penyelidikan individual maupun kelompok, mengembangkan dan menyajikan hasil karya, dan Imenganalisis dan mengevaluasi proses pemecahan masalah. Analisis data yang digunakan selama pengembangan adalah analisis diskriptif, analisis kelayakan modul berdasarkan skor kriteria dan analisis keterampilan berfikir kritis dengan $t$ test. Hasil penelitian ini adalah (1) modul IPA berbasis masalah untuk meningkatkan keterampilan berpikir kritis siswa memiliki ciri yaitu langkah pembelajaran pada modul disesuaikan dengan langkah pembelajaran berbasis masalah, mengintegrasikan keterampilan berpikir kritis pada setiap tahapnya dan memuat soal tes berpikir kritis (2) kualitas modul IPA berbasis masalah untuk meningkatkan keterampilan berpikir kritis siswa pada materi litosfer yang dikembangkan memiliki skor rata-rata persentase sebesar 90,16\% dan berkategori sangat baik yang berarti modul layak untuk digunakan sebagai penunjang bahan ajar lainnya, (3) keterampilan berpikir kritis siswa pada kelas IX.B setelah menggunakan modul IPA berbasis masalah mengalami peningkatan yang dapat dilihat dari nilai $\mathrm{N}$-gain dari uji coba skala besar sebesar 0,69 dikategorikan "sedang" dengan signifikansi sebesar 0,000. Berdasarkan hasil gain score menunjukkan modul IPA berbasis masalah dapat meningkatkan keterampilan berpikir kritis.
\end{abstract}

Kata kunci: Modul, Pembelajaran Berbasis Masalah, Keterampilan Berpikir Kritis

\section{Pendahuluan}

Pendidikan IPA di Indonesia belum mencapai standar yang diinginkan, padahal untuk memajukan ilmu pengetahuan dan teknologi (IPTEK) merupakan hal penting dan menjadi tolak ukur kemajuan bangsa. Kenyataannya, berdasarkan hasil laporan 
beberapa lembaga internasional, perkembangan pendidikan di Indonesia masih belum memuaskan. Hal ini tercermin dari hasil Study Programme For International Student Assessment (PISA) 2012 menunjukkan sistem pendidikan Indonesia masih kurang baik. Jumlah anggota PISA dari 65 negara, pendidikan Indonesia berada pada peringkat 64. Selain itu dari hasil Survei Trends in International Mathematics and Science Study (TIMSS) tahun 2007 yang diikuti oleh sekitar 425.000 siswa dari 59 negara peserta dan 8 negara yang menjadi pembanding (benchmarking participants) pada survei kelas IV dan kelas VIII, kemampuan anak-anak Indonesia dalam bidang sains menempati urutan 35 (nilai rata-rata 427). Menurut Mullis dkk (2007) skor ini tergolong ke dalam kategori low benchmark artinya siswa baru mengenal konsep mendasar dalam fisika dan biologi.

Kecenderungan pembelajaran IPA pada masa kini adalah peserta didik hanya mempelajari IPA sebagai produk, menghafalkan konsep, prinsip, hukum, dan teori. Keadaan ini diperparah oleh pembelajaran yang hanya berpusat pada guru (teacher center). Akibatnya IPA sebagai sikap, proses, dan aplikasi tidak tersentuh dalam pembelajaran.

Berdasarkan observasi awal dan analisis kebutuhan siswa dengan koresponden siswa di SMP Nawa Kartika Selogiri, Kabupaten Wonogiri, banyak siswa yang mengganggap bahwa pelajaran IPA merupakan pelajaran yang sulit dipahami karena tidak menarik. Hal tersebut senada dengan hasil wawancara terhadap guru IPA bahwa penguasaan siswa terhadap pelajaran IPA masih rendah. Menurut keterangan yang diperoleh dari guru tersebut hal ini disebabkan karena minat siswa terhadap IPA kurang bahkan dalam belajar sehari-hari siswanya cenderung pasif. Pembelajaran sebagian besar dengan ceramah, dan belum melatih siswa pada keterampilan berpikir kritis. Siswa jarang dihadapkan dengan permasalahan secara langsung dalam kehidupan sehari-hari sehingga keterampilan berpikir kritis siswa kurang dan cenderung menghafal apa yang ada di buku saja. Selain itu bahan ajar yang tersedia di sekolah juga terbatas, sekolah tidak dapat meminjamkan buku karena keterbatasan bahan ajar yang tersedia di perpustakaan.

Hasil angket analisis kebutuhan siswa menunjukkan bahwa: 1) pembelajaran IPA fisika di SMP Nawa Kartika Wonogiri menggunakan bahan ajar yang sesuai dengan kurikulum KTSP, 2) bahan ajar yang sesuai kurikulum KTSP hanya ada satu macam dari penerbit global dan jumlahnya juga terbatas dibandingkan jumlah siswa, 3) siswa hanya memiliki LKS yang dikeluarkan dari MGMP dinas pendidikan daerah setempat, 4) peserta didik lebih menyukai bahan ajar berbentuk cetak karena SMP Nawa Kartika adalah sekolah boarding school, semua peserta didik wajib di asrama dan dilarang membawa media elektronik termasuk internet, 5) pembelajaran IPA hanya kadang-kadang saja menggunakan pembelajaran berbasis masalah dan cenderung dengan metode ceramah saja dan tanya jawab saja, 6) siswa lebih pasif dalam pembelajaran dan belum melatih siswa pada keterampilan berpikir kritis, hal ini terlihat dari persentase keterampilan berpikir kritis yang kurang dari $50 \%$ pada setiap aspeknya, serta 8) materi pada bahan ajar yang digunakan belum memuat materi yang lengkap.

Hansen \& Lovedahl (2004) menyatakan bahwa belajar dengan melakukan merupakan sarana belajar yang efektif, artinya seseorang akan belajar efektif bila ia melakukan. Oleh karena itu, modul yang dikembangkan di dalam penelitian ini menerapkan pembelajaran berbasis masalah dengan harapan pembelajaran IPA dapat terlaksana dengan mengedepankan pemecahan masalah secara langsung oleh siswa. Pada PBL pembelajarannya lebih mengutamakan proses belajar, tugas guru harus memfokuskan diri untuk membantu siswa, mencapai keterampilan mengarahkan diri. Guru dalam model ini berperan sebagai penyaji masalah, penanya, mengadakan dialog, membantu menemukan masalah, dan pemberi fasilitas pembelajaran. Selain itu, guru memberikan dukungan yang dapat meningkatkan pertumbuhan inkuiri dan intelektual siswa. Model ini hanya dapat terjadi jika guru dapat 
menciptakan lingkungan kelas yang terbuka dan membimbing pertukaran gagasan.

Menurut La Iru dan La Ode (2012) pembelajaran berbasis masalah (problem based learning) merupakan salah satu model pembelajaran yang banyak digunakan karena banyak mengembangkan kemampuan keterampilan berpikir tingkat tinggi. Pembelajaran artinya dihadapkan pada suatu masalah, yang kemudian dengan melalui pemecahan masalah, melalui masalah tersebut siswa belajar keterampilan-keterampilan yang lebih mendasar. Arends dalam Harahap (2008) mengemukakan ada 5 fase (tahap) yang perlu dilakukan untuk mengimplementasikan PBL, yaitu: orientasi pada situasi masalah, merumuskan hipotesis, penyelidikan, mengembangkan dan menyajikan hasil karya, dan menganalisis dan mengevaluasi proses pemecahan masalah. La Iru dan La Ode (2012) mengatakan bahwa pembelajaran berdasarkan masalah memiliki keunggulan diantaranya dapat mengembangkan kemampuan ilmiah dan keterampilan berpikir kritis. Menurut Scriven dan Paul (dalam Liliasari dan Tawil, 2013) berpikir kritis didefinisikan sebagai proses disiplin yang secara intelektual aktif dan terampil mengkonseptualisasi, menerapkan, menganalisis, mensistensis dan mengevaluasi informasi yang dikumpulkan dari atau dihasilkan oleh pengamatan, pengalaman, refleksi, penalaran, atau komunikasi, sebagai panduan untuk kepercayaan dan tindakan. Dalam penelitian ini dikembangkan modul pembelajaran yang salah satu karakteristik dari modul itu sendiri adalah melatih keterampilan berpikir kritis siswa. Indikator keterampilan berpikir kritis yang dipakai berdasarkan indikator keterampilan berpikir kritis Ennis (1996), yaitu: memberi penjelasan, membangun keterampilan dasar, interferensi, membuat penjelasan lebih lanjut, dan strategi dan taktik.

Salah satu solusi yang ditawarkan untuk mengatasi permasalahan tersebut adalah dengan mengembangkan modul pembelajaran berbasis masalah. Melalui modul ini, siswa diharapkan mampu merumuskan masalah, merumuskan hipotesis, melakukan penyelidikan, mengembangkan dan menyajikan hasil karya, dan menganalisis dan mengevaluasi proses pemecahan masalah sehingga akan meningkatkan meningkatkan keterampilan berpikir kritisnya. Proses pembelajaran idealnya dapat melibatkan siswa secara aktif dan berpusat pada siswa (student centered) terkait dengan permasalahan dalam kehidupan sehari-hari.

Dengan pengembangan modul pembelajaran berbasis masalah ini, siswa diharapkan mampu mengembangkan keterampilan-keterampilan berupa merumuskan masalah, merumuskan hipotesis, melakukan penyelidikan, mengembangkan dan menyajikan hasil karya, menganalisis dan mengevaluasi proses pemecahan masalah dalam proses-proses pembelajaan untuk membuktikan suatu konsep, dengan begitu keterampilan berpikir kritis siswa akan meningkat. Penelitian ini bertujuan untuk merancang dan menyusun modul pembelajaran berbasis masalah, serta mengetahui pengaruh modul terhadap keterampilan berpikir kritis siswa SMP.

\section{Metode Penelitian}

\section{Model Penelitian dan Pengembangan}

Penelitian ini dilaksanakan di SMP Nawa Kartika, Jalan Solo-Wonogiri Km. 25, Wonogiri, Jawa Tengah dari bulan Februari 2015 sampai Januari 2016. Metode dan rancangan penelitian menggunakan desain Research and Development (R\&D) dari Thiagarajan (1974), langkah-langkahnya: pendefinisian (Define), Perencanaan (Design), pengembangan (Develop), dan penyebaran (Disseminate).

Uji coba produk digunakan untuk mengumpulkan data terkait produk yang dikembangkan yaitu modul pembelajaran berbasis masalah sehingga dapat diketahui kelayakan produk. Uji coba yang dilakukan antara lain: uji coba produk awal berupa validasi ahli, validasi praktisi pendidikan (guru), dan validasi peer review, uji coba skala kecil yang dilakukan pada 15 siswa kelas IX.A SMP Nawa Kartika yang diambil berdasarkan peringkat 1 sampai 15 , dan uji 
coba skala besar yang dilakukan di kelas IX.B yang berjumlah 24 siswa.

Instrumen penelitian merupakan alat atau fasilitas yang digunakan oleh peneliti dalam mengumpulkan data agar hasilnya lebih baik, dalam arti lebih cermat, lengkap, dan sistematis sehingga lebih mudah diolah (Arikunto, 2010). Secara garis besar, instrumen pengumpulan data dalam penelitian ini antara lain berupa: angket, lembar validasi, soal tes, dan lembar observasi.

Teknik analisis data yang digunakan dalam penelitian ini adalah analisis deskriptif kuantitatif dan kualitatif, yaitu dengan mendeskripsikan dan memaknai data yang bersifat kuantitatif maupun kualitatif. Sebelum dianalisis, dilakukan proses kuantifikasi data, selanjutnya data tersebut dianalisis dengan menggunakan statistik deskriptif. Untuk data hasil wawancara, dan dokumentasi dianalisis dengan analisis kualitatif. Analisis data yang dilakukan dalam penelitian ini berupa: data analisis kebutuhan, data hasil validasi oleh ahli, praktisi, dan peer review, data uji skala kecil, dan data dari uji skala besar. Data yang didapatkan dalam uji besar antara lain: analisis keterampilan berpikir kritis (hasil belajar kognitif), analisis hasil belajar afektif, analisis hasil belajar psikomotorik, dan analisis sintaks keterlaksanaan pembelajaran.

\section{Hasil Penelitian dan Pembahasan}

\section{Hasil Pendefinisian}

Materi yang dipilih adalah materi litosfer. Hal ini karena pada materi litosfer, guru jarang menjelaskan langsung. Peserta didik cenderung disuruh membaca dan mempelajari materi ini secara mandiri. Hal ini karena guru memiliki pemikiran bahwa materi litosfer merupakan materi terakhir kelas 9 semester 2 dan hanya berisi teori yang bisa dipelajari sendiri oleh peserta didik, sehingga guru terkadang tidak menjelaskan materi ini tetapi malah mengejar materi lain untuk persiapan ujian nasional. Kajian pembelajaran yang dikembangkan sesuai dengan Kurikulum KTSP pada KD 5.4 mendeskripsikan prosesproses khusus yang terjadi di lapisan litosfer dan atmosfer yang terkait dengan perubahan zat dan kalor dan KD 5.5 menjelaskan hubungan antara proses yang terjadi di lapisan litosfer dan atmosfer dengan kesehatan dan permasalahan lingkungan. Hasil dari analisis kebutuhan dari guru IPA dan materi, dijadikan dasar untuk mengembangkan modul pembelajaran berbasis masalah pada materi litosfer yang merujuk pada standar yang telah ditetapkan BSNP tentang standar pengembangan modul dan buku teks pelajaran. Dinamakan modul pembelajaran berbasis masalah karena modul disusun berdasarkan langkah pembelajaran berbasis masalah.

\section{Hasil Perencanaan}

Pada tahap perencanaan didapat hasil pemilihan format dan desain awal modul. Pemilihan format disesuaikan dengan format kriteria modul yang diadaptasi dari pendapat Sanjaya (2011) yang disusun berdasarkan langkah pembelajaran berbasis masalah dan dimodifikasi peneliti dengan menambahkan keterampilan berpikir kritis yang terintegrasi dalam model pembelajaran berbasis masalah. Langkah-langkah pembelajaran berbasis masalah meliputi: 1) merumuskan masalah, 2) merumuskan hipotesis, 3) penyelidikan, 4) menyimpulkan dan menyajikan hasil karya, dan 5) merumuskan rekomendasi pemecahan masalah.

Pada tahap desain awal modul yang dikembangkan dilakukan penyusunan modul yang akan menghasilkan draf desain modul yang didalamnya mencakup: judul modul, halaman francis, kata pengantar, pendahuluan, standar kompetensi dan kompetensi dasar, bagian modul, peta konsep, dan daftar isi.

\section{Hasil Pengembangan}

Desain modul dikembangkan menjadi draf I modul pembelajaran berbasis masalah pada materi litosfer terdiri dari dua sub materi. Sub materi I dengan menganalisis konsep batuan dan sub materi II dengan menganalisis tenaga geologi. Draft I kemudian divalidasi oleh ahli materi, ahli media, ahli bahasa, guru IPA, dan peer review untuk memperoleh saran dan masukan terhadap modul. Data hasil dari validasi dapat dilihat pada Tabel 1.

Tabel 1. Hasil Validasi Modul 
JURNAL INKUIRI

ISSN: 2252-7893, Vol. 6, No. 3, 2017 (hal 141-152)

http://jurnal.uns.ac.id/inkuiri

\begin{tabular}{|c|c|c|c|c|}
\hline Validasi & Validator & Skor & $\begin{array}{c}\text { Rata- } \\
\text { rata }\end{array}$ & Kriteria \\
\hline $\begin{array}{l}\text { Kelayakan } \\
\text { isi }\end{array}$ & $\begin{array}{l}\text { Ahli } \\
\text { materi }\end{array}$ & 30 & 3,75 & $\begin{array}{c}\text { Sangat } \\
\text { baik }\end{array}$ \\
\hline $\begin{array}{l}\text { Kelayakan } \\
\text { penyajian }\end{array}$ & $\begin{array}{l}\text { Ahli } \\
\text { materi }\end{array}$ & 30 & 3,75 & $\begin{array}{c}\text { Sangat } \\
\text { baik }\end{array}$ \\
\hline \multirow[t]{3}{*}{$\begin{array}{l}\text { Kelayakan } \\
\text { bahasa }\end{array}$} & $\begin{array}{l}\text { Ahli } \\
\text { bahasa }\end{array}$ & 28 & 4 & $\begin{array}{c}\text { Sangat } \\
\text { baik }\end{array}$ \\
\hline & Guru IPA & 25 & 3,57 & $\begin{array}{c}\text { Sangat } \\
\text { baik }\end{array}$ \\
\hline & $\begin{array}{l}\text { Peer } \\
\text { review }\end{array}$ & 26 & 3,71 & $\begin{array}{c}\text { Sangat } \\
\text { baik }\end{array}$ \\
\hline \multirow[t]{3}{*}{$\begin{array}{l}\text { Kelayakan } \\
\text { kegrafikan }\end{array}$} & $\begin{array}{l}\text { Ahli } \\
\text { media }\end{array}$ & 96 & 3,43 & Baik \\
\hline & Guru IPA & 112 & 4 & $\begin{array}{c}\text { Sangat } \\
\text { baik }\end{array}$ \\
\hline & $\begin{array}{l}\text { Peer } \\
\text { review }\end{array}$ & 97 & 3,46 & Baik \\
\hline Rata-rata & & 444 & 3,71 & $\begin{array}{c}\text { Sangat } \\
\text { baik }\end{array}$ \\
\hline
\end{tabular}

Setelah validasi, kemudian dilakukan revisi berdasarkan saran dan masukan dari para validator. Setelah revisi selesai dilaksanakan, maka tahap selanjutnya adalah uji skala kecil. Uji skala kecil ini dilakukan di kelas IX.A untuk mengetahui tingkat keterbacaan modul. Hasil tanggapan siswa dari uji skala kecil didapatkan rata-rata 91,5\% dengan kategori modul sangat baik.

Setelah dilakukan uji skala kecil, langkah selanjutnya adalah dilakukan proses uji skala besar. Dalam uji besar, data yang didapat adalah hasil sintaks keterlaksanaan, hasil pembelajaran hasil belajar afektif, hasil belajar psikomotorik, hasil belajar kognitif (keterampilan berpikir kritis), dan hasil respon siswa terhadap modul.

Tabel 2. Hasil keterlaksanaan sintaks pembelajaran berbasis masalah

\begin{tabular}{|c|c|c|c|c|}
\hline \multirow{2}{*}{$\begin{array}{c}\text { Objek } \\
\text { Pengamatan }\end{array}$} & \multicolumn{2}{|c|}{ Observer (\%) } & \multirow{2}{*}{$\begin{array}{c}\text { Rata- } \\
\text { rata } \\
(\%)\end{array}$} & \multirow[t]{2}{*}{ Kategori } \\
\hline & I & II & & \\
\hline \multicolumn{5}{|l|}{ Aktivitas Guru } \\
\hline $\begin{array}{c}\text { Kegiatan Belajar } \\
1\end{array}$ & $75 \%$ & $85 \%$ & $80 \%$ & Baik \\
\hline $\begin{array}{c}\text { Kegiatan Belajar } \\
2\end{array}$ & $95 \%$ & $90 \%$ & $92,5 \%$ & $\begin{array}{l}\text { Sangat } \\
\text { Baik }\end{array}$ \\
\hline $\begin{array}{c}\text { Kegiatan Belajar } \\
3\end{array}$ & $95 \%$ & $95 \%$ & $95 \%$ & $\begin{array}{l}\text { Sangat } \\
\text { Baik }\end{array}$ \\
\hline \multicolumn{3}{|c|}{ Rata-rata keseluruhan pertemuan } & $\begin{array}{c}89,17 \\
\%\end{array}$ & $\begin{array}{l}\text { Sangat } \\
\text { Baik }\end{array}$ \\
\hline \multicolumn{5}{|l|}{ Aktivitas Siswa } \\
\hline $\begin{array}{c}\text { Kegiatan Belajar } \\
1\end{array}$ & $70 \%$ & $75 \%$ & $72,5 \%$ & Baik \\
\hline$\underset{2}{\text { Kegiatan Belajar }}$ & $85 \%$ & $90 \%$ & $87,5 \%$ & $\begin{array}{l}\text { Sangat } \\
\text { Baik }\end{array}$ \\
\hline $\begin{array}{c}\text { Kegiatan Belajar } \\
3\end{array}$ & $95 \%$ & $95 \%$ & $95 \%$ & $\begin{array}{l}\text { Sangat } \\
\text { Baik }\end{array}$ \\
\hline \multicolumn{3}{|c|}{ Rata-rata keseluruhan pertemuan } & $85 \%$ & $\begin{array}{l}\text { Sangat } \\
\text { Baik }\end{array}$ \\
\hline
\end{tabular}

Penilaian hasil belajar afektif dan psikomotorik siswa dilakukan selama berlangsungnya proses pembelajaran dengan penilaian menggunakan lembar observasi dan dinilai oleh dua observer. Analisa data hasil belajar afektif dan psikomotorik siswa disajikan pada Tabel 3 .

Tabel 3. Hasil Belajar Afektif dan Psikomotorik

\begin{tabular}{|c|c|c|c|c|}
\hline \multirow[t]{2}{*}{ Kegiatan } & \multicolumn{2}{|c|}{ Observer } & \multirow{2}{*}{$\begin{array}{l}\text { Rata- } \\
\text { rata }\end{array}$} & \multirow[t]{2}{*}{ Kategori } \\
\hline & I & II & & \\
\hline \multicolumn{5}{|c|}{ Hasil Belajar Afektif } \\
\hline $\begin{array}{l}\text { Kegiatan } \\
\text { Belajar } 1\end{array}$ & 75,83 & 77,086 & 76,46 & Baik \\
\hline $\begin{array}{l}\text { Kegiatan } \\
\text { Belajar } 2\end{array}$ & 76,88 & 82,71 & 79,79 & Baik \\
\hline $\begin{array}{l}\text { Kegiatan } \\
\text { Belajar } 3 \\
\end{array}$ & 92,08 & 97,29 & 95 & $\begin{array}{c}\text { Sangat } \\
\text { Baik }\end{array}$ \\
\hline Rata-rata k & ruhan $\mathrm{p}$ & muan & 83,75 & $\begin{array}{c}\text { Sangat } \\
\text { Baik }\end{array}$ \\
\hline \multicolumn{5}{|c|}{ Hasil Belajar Psikomotorik } \\
\hline $\begin{array}{l}\text { Kegiatan } \\
\text { Belajar } 1\end{array}$ & 76,87 & 78,76 & 77,8 & Baik \\
\hline $\begin{array}{l}\text { Kegiatan } \\
\text { Belajar } 2 \\
\end{array}$ & 77,92 & 77,29 & 77,61 & Baik \\
\hline $\begin{array}{l}\text { Kegiatan } \\
\text { Belajar } 3 \\
\end{array}$ & 86,77 & 88,96 & 87,86 & $\begin{array}{c}\text { Sangat } \\
\text { Baik }\end{array}$ \\
\hline \multicolumn{3}{|c|}{ Rata-rata keseluruhan } & 81,09 & $\begin{array}{c}\text { Sangat } \\
\text { Baik }\end{array}$ \\
\hline
\end{tabular}

Data hasil belajar kognitif (hasil keterampilan berpikir kritis) siswa diperoleh melalui nilai pretest dan posttest. Nilai pretest diperoleh sebelum siswa menggunakan modul IPA yang dikembangkan dan nilai posttest diperoleh setelah menggunakan modul IPA. 
Hasil rata-rata pretest diperoleh 53,13 dengan nilai minimum 15 dan nilai maksimum 81 . Sedangkan rata-rata nilai posttest diperoleh 86,42 dengan nilai minimum 62 dan nilai maksimum 98. Hasil analisis nilai pretest dan posttest disajikan pada Tabel 4.

Tabel 4. Ringkasan Hasil Analisis Nilai Pretest dan

\begin{tabular}{|c|c|c|c|}
\hline \multicolumn{4}{|c|}{ Posttest } \\
\hline Uji & Jenis Uji & Hasil & Keputusan \\
\hline Normalitas & $\begin{array}{l}\text { Kolmogorov } \\
\text { Smirnov }\end{array}$ & $\begin{array}{l}\text { Sig pretest } \\
=0,200 \\
\text { Sig posttest } \\
=0,200\end{array}$ & $\mathrm{H}_{0}$ diterima \\
\hline Homogenitas & Levene Test & Sig 0,150 & $\mathrm{H}_{0}$ diterima \\
\hline $\begin{array}{l}\text { Hasil } \\
\text { Pretest- } \\
\text { Posttest }\end{array}$ & t-test & $\begin{array}{l}\text { Sig. } \\
\text { tailed })= \\
0,000\end{array}$ & $\mathrm{H}_{0}$ ditolak \\
\hline
\end{tabular}

Berdasarkan Tabel 4, diperoleh hasil pengujian normalitas menggunakan uji Kolmogorov-Smirnov terlihat bahwa nilai pretest dan posttest diperoleh signifikansi 0,200 dan 0,200 yang berarti nilai signifikansinya lebih dari 0,05 . Oleh karena itu, disimpulkan bahwa data yang diperoleh baik dari nilai pretest maupun posttest berdistribusi normal. Hasil pengujian homogenitas menggunakan uji Levene diperoleh signifikansi 0,15 sehingga Ho diterima, kesimpulannya varians data homogen. Pengolahan data statistik menggunakan SPSS 20 diperoleh hasil Sig. (2tailed) di bawah 0,05 yaitu 0,000. Dapat disimpulkan $\mathrm{H}_{0}$ ditolak yang berarti dibahwa terdapat terdapat perbedaan rata-rata keterampilan berpikir kritis siswa sebelum dan sesudah menggunakan modul IPA berbasis masalah. Hasil lembar observasi keterampilan berpikir kritis pada setiap kegiatan belajar dapat dilihat pada Gambar 1.
Gambar 1. Histogram Keterampilan Berpikir Kritis Siswa

Hasil kegiatan belajar seluruhnya didapatkan bahwa keterampilan berpikir kritis yang paling menonjol di kelas IX.B adalah keterampilan membangun keterampilan dasar yang di dalamnya meliputi keterampilan mengamati, hal ini terlihat hampir seluruh siswa melakukan pengamatan dengan benar. Sedangkan skor terendah adalah keterampilan memberikan strategi dan taktik, ada beberapa siswa yang masih pasif dalam proses pembelajaran. Pada akhir pembelajaran, siswa mengisi angket untuk mengetahui respon siswa terhadap modul. Hasil respon siswa terhadap modul terlihat pada Tabel 5 .

Tabel 5. Hasil respon siswa terhadap modul

\begin{tabular}{lccccc}
\hline \multicolumn{1}{c}{ Aspek } & Indikator & Skor & Ps $(\%)$ & $\begin{array}{c}\text { Ps } \\
\text { rata- } \\
\text { rata } \\
(\%)\end{array}$ & Kategori \\
Kelayakan & 1 & 79 & 82,29 & 80,21 & $\begin{array}{c}\text { Sangat } \\
\text { baik }\end{array}$ \\
Isi & 2 & 80 & 83,33 & & \\
Kelayakan & 3 & 72 & 75 & & Sangat \\
Penyajian & 5 & 95 & 98,96 & 94,1 & baik \\
& 5 & 93 & 96,88 & & \\
Kelayakan & 7 & 83 & 86,46 & & Sangat \\
Bahasa & 8 & 87 & 98,54 & 90,28 & \\
& 9 & 88 & 91,67 & & baik \\
Kegrafikan & 10 & 82 & 85,42 & 83,93 & Sangat \\
& 11 & 83 & 86,46 & & baik \\
Rata-rata skor & 12 & 77 & 80,21 & & Sangat \\
& & 83,67 & 87,13 & 87,13 & baik \\
\hline
\end{tabular}

\section{Hasil Diseminasi}

Tahapan terakhir setelah dilakukan uji coba skala besar adalah tahap disseminasi pada SMP di Kabupaten Wonogiri. Hasil dari tahap diseminasi ditunjukkan pada Tabel 6 . 
JURNAL INKUIRI

ISSN: 2252-7893, Vol. 6, No. 3, 2017 (hal 141-152)

http://jurnal.uns.ac.id/inkuiri

Tabel 6. Hasil Kuesioner Tahapan Diseminasi Produk

\begin{tabular}{llcc}
\hline No. & \multicolumn{1}{c}{ Aspek } & Rata-rata $(\%)$ & Kategori \\
\hline 1. & Kelayakan isi & 85 & Sangat Baik \\
2. & Kelayakan & 91,67 & Sangat Baik \\
3. & Kenyajian & 86,67 & Sangat Baik \\
4. & Kegrafikan bahasa & 93,33 & Sangat Baik \\
\hline \multicolumn{2}{l}{ Rata-rata } & 89,17 & Sangat Baik \\
\hline
\end{tabular}

\section{Pembahasan}

\section{Tahap Pendefinisian}

Tahapan ini dilakukan penyebaran angket kebutuhan kepada siswa dan guru mengenai pembelajaran IPA di sekolah. Hasil dari angket pengungkap kebutuhan siswa adalah siswa membutuhkan bahan ajar cetak yang sesuai dengan kurikulum KTSP. Siswa belum menggunakan model pembelajaran berbasis masalah dalam pembelajaran. Selain itu, siswa belum diarahkan pada keterampilan berpikir kritis. Siswa membutuhkan bahan ajar dengan materi yang lengkap dan siswa setuju bila dikembangkan bahan ajar modul pembelajaran berbasis masalah untuk meningkatkan keterampilan berpikir kritis siswa.

Materi IPA yang akan dikembangkan adalah materi litosfer, dimana pada silabus disebutkan pada Kompetensi Dasar (KD) 5.4 dan 5.5. Pengembangan modul IPA ini mengangkat materi litosfer, dengan alasan materi litosfer merupakan materi terakhir kelas 9 semester 2 dan hanya berisi teori yang bisa dipelajari sendiri oleh peserta didik, sehingga guru terkadang tidak menjelaskan materi ini tetapi malah mengejar materi lain untuk persiapan ujian nasional. Sehingga diharapkan dengan modul ini akan membantu dan lebih memudahkan siswa dalam mempelajari modul dan materi yang akan disajikan.

Hasil angket pengungkap kebutuhan guru dan siswa yang telah dilakukan diperoleh kesimpulan bahwa dalam proses pembelajaran dibutuhkan bahan ajar cetak yang sesuai dengan kurikulum KTSP, guru dan siswa setuju bila dikembangkan modul pembelajaran berbasis masalah untuk meningkatkan keterampilan berpikir kritis. Seperti penelitian Hartati (2015) yang menunjukkan bahwa penerapan model PBL pada pembelajaran IPA terpadu memiliki dampak yang positif terhadap peningkatan kemampuan berpikir kritis siswa.

\section{Tahap Perencanaan}

Hasil dari studi pendahuluan digunakan sebagai dasar tahap perencanaan, tahap perencanaan meliputi pemilihan format berdasarkan kriteria modul dan desain awal modul. Format kriteria modul yang dikembangkan diadaptasi dari pendapat Sanjaya (2011) yaitu menggunakan unsurunsur modul meliputi: (1) judul modul, (2) petunjuk umum, (3) tujuan yang harus dicapai, (4) krtiteria keberhasilan, (5) peta konsep, (6) materi pembelajaran, (7) rangkuman materi, (8) tugas dan latihan, (9) soal evaluasi, (10) kunci jawaban, (11) glosarium dan (12) daftar pustaka. Modul ini juga disusun berdasarkan langkah pembelajaran berbasis masalah. Pembelajaran berbasis masalah dipilih karena dapat merangsang berpikir tingkat tinggi. Hal ini sesuai dengan penelitian Ersoy dan Baser (2014) yang menyatakan bahwa problem based learning dalam pembelajaran mampu meningkatkan keterampilan berpikir kritis siswa.

Desain awal modul yang dikembangkan merupakan bagian pendahuluan dari modul yang mencakup: (1) judul modul, (2) halaman francis, (3) kata pengantar, (4) pendahuluan, (5) standar kompetensi dan kompetensi dasar, (6) bagian modul, (7) peta konsep, dan (8) daftar isi. Cover pada modul berukuran A4 berisikan logo Universitas, judul modul, tujuan dibuat modul untuk kelas IX, gambar-gambar pendukung dan penyusun. Pada halaman francis terdapat logo universitas, judul utama modul, tujuan dibuat modul untuk kelas IX, penyusun, konsultan ahli, dan validator ahli. Setelah halaman francis terdapat kata pengantar, pendahuluan (berisi deskripsi umum, prasyarat, dan petunjuk penggunaan modul), SK dan KD, bagian-bagian modul, peta konsep yang menggambarkan materi litosfer, dan daftar isi. Desain awal modul ini kemudian dikembangkan menjadi draft I pada tahap pengembangan. Draft I akan divalidasi oleh ahli terlebih dahulu sebelum diujicobakan skala kecil. Pada tahap ini dikembangkan 
juga pola keterkaitan antara PBL dan keterampilan berpikir kritis siswa.

\section{Tahap Pengembangan}

Hasil draft modul yang dikembangkan adalah modul pembelajaran berbasis masalah untuk meningkatkan keterampilan berpikir kritis siswa SMP pada materi litosfer. Modul bersifat sistematis karena disusun secara runtut sehingga dapat memudahkan siswa dalam belajar. Instrumen penelitian yang digunakan yaitu angket, lembar validasi, lembar observasi untuk penilaian, soal try out uji coba dan evaluasi. Try out soal keterampilan berpikir kritis dilakukan pada 10 siswa kelas IX.A SMP Nawa Kartika. Analisis butir soal dilakukan dengan menggunakan software SPSS dan excel untuk mengetahui validitas, reliabilitas, indeks kesukaran, dan daya pembeda soal. Kesimpulan yang didapat 10 soal valid untuk digunakan sebagai tes keterampilan berpikir kritis siswa.

Uji coba produk awal yaitu tahap dilakukan validasi ahli, praktisi pendidikan dan peer review. Validasi ahli dilakukan oleh ahli materi modul, ahli media modul, dan ahli bahasa. Validasi praktisi pendidikan dilakukan oleh satu guru IPA. Validasi peer review dilakukan oleh mahasiswa yang menempuh pendidikan magister dalam bidang keilmuan pendidikan fisika. Berdasarkan hasil validasi ahli materi yang ditunjukkan pada Tabel 1, diperoleh rata-rata keseluruhan aspek sebesar 3,75 dan memiliki kategori "sangat baik". Aspek kedalaman materi, keakuratan ilustrasi, keterkaitan fitur, contoh, dan rujukan mendapatkan nilai kurang dari 4 karena dinilai masih kurang, sehingga dilakukan revisi. Hasil validasi modul pada kelayakan bahasa diperoleh skor hasil validasi dari validator ahli bahasa yaitu 4. Menurut validator ahli bahasa, bahasa yang dipakai dalam modul dalam modul sudah sesuai dan tidak memunculkan salah penafsiran. Skor hasil validasi bahasa oleh guru IPA adalah 3,57, aspek kesesuaian dengan tingkat perkembangan sosial emosional, keterpahaman pesan, kebakuan istilah dan simbol mendapat nilai 3. Hal ini dikarenakan masih ada beberapa kata-kata ilmiah yang sulit dipahami siswa dan perlu ditambahkan glosarium di akhir sub materi. Hasil validasi bahasa oleh peer review adalah 3,71. Pada aspek ketepatan tata bahasa dan ejaan mendapat nilai 3 karena ada beberapa tanda baca dalam soal evaluasi yang penulisannya belum sesuai dengan ejaan yang benar. Sehingga diperoleh rata-rata hasil validasi modul pada kelayakan bahasa sebesar 3,76 dengan kriteria sangat baik.

Berdasarkan hasil validasi praktisi yang ditunjukkan pada Tabel 1, diperoleh rata-rata keseluruhan aspek 3,78 dan memiliki kategori "sangat baik". Aspek metode penyajian, ilustrasi, dan aspek fisik perlu dilakukan revisi. Karena menurut guru, perlu ada alokasi yg jelas pada tahapan-tahapan yang terdapat didalam modul. Revisi juga dilakukan pada gambar yang dimuat didalam modul. Sedangkan hasil validasi kegrafikan pada Tabel 1, diperoleh rata-rata hasil validasi modul pada kelayakan kegrafikan sebesar 3,63 dengan kriteria sangat baik. Ada beberapa aspek yang mendapat nilai 3. Hal ini diantaranya karena ada gambar pada cover depan yang kurang ilustratif, warna pada halaman daftar isi tidak kontras, letak judul sub materi kurang harmonis, tata letak pengarang dan ilustrasi yang kurang tepat, dan icon pembelajaran yang kurang tepat.

Setelah divalidasi, modul kemudian dilakukan revisi produk I berdasarkan masukan atau saran untuk diadakan perbaikan sebelum diujikan pada uji coba kecil. Hasil saran dan masukan dari para ahli dan praktisi digunakan sebagai perbaikan pada materi, desain modul, dan perangkat, kemudian dilakukannya revisi dan selanjutnya produk modul akan digunakan pada uji coba kecil.

Uji coba kecil dilakukan oleh lima belas orang siswa. Hasil data yang diperoleh berupa tanggapan siswa terhadap modul. Data hasil tanggapan siswa pada uji coba kecil tersebut, kemudian dilakukan revisi sesuai dengan temuan siswa saat melakukan seluruh tahapan yang ada didalam modul, memperbaiki kalimat yang masih sulit dimengerti oleh siswa. Setelah dilakukan revisi, maka selanjutnya dilaksanakan uji coba skala besar untuk menerapkan modul dalam pembelajaran. Hasil saran dan masukan dari uji coba kecil lima 
belas siswa digunakan sebagai bahan perbaikan, setelah modul diperbaiki maka digunakan uji coba skala besar.

Uji coba skala besar dilakukan pada kelas IX.B. Pada kelas IX.B terdiri dari 24 siswa. Data diperoleh tahap uji coba skala besar adalah data hasil keterlaksanaan pembelajaran, hasil belajar afektif, hasil belajar psikomotor, hasil belajar kognitif (hasil keterampilan berpikir kritis), dan respon siswa terhadap modul.

Keterlaksanaan sintaks pembelajaran berdasarkan aktivitas guru dan siswa dari Tabel 2 diperoleh yang dikategorikan sangat baik. Kategori sangat baik berarti aktivitas guru dan siswa pada proses pembelajaran menggunakan modul IPA sudah sesuai dengan sintaks pembelajaran berbasis masalah yang digunakan.

Penilaian afektif siswa meliputi: rasa ingin tahu, kerja keras, jujur, menghargai prestasi, dan komunikatif. Pada pertemuan 1, 2 , dan 3 terlihat skor rata-rata yang diperoleh meningkat. Hal ini sesuai dengan Etherington (2011) pembelajaran dinyatakan berhasil membuat siswa aktif dengan menggunakan pembelajaran berbasis masalah.

Hasil belajar psikomotorik rata-rata adalah $81,09 \%$ yang dikategorikan sangat baik. Pada pertemuan 2 terjadi sedikit penurunan hasil psikomotorik siswa. Hal ini terjadi karena ada beberapa istilah dan konsep tentang "gempa bumi" yang masih belum dimengerti oleh beberapa siswa. Ada beberapa siswa yang masih memerlukan bimbingan guru dalam menyimpulkan percobaan. Menurut Ibrahim (2005) hasil belajar psikomotorik merupakan suatu keterampilan yang didapatkan oleh seseorang dengan melibatkan koordinasi antara indra dan otot. Pada penelitian ini siswa melibatkan koordinasi indra dan otot karena siswa terlibat langsung dalam melakukan percobaan.

Data hasil belajar kognitif yang diperoleh dari uji coba skala besar adalah data pretest dan posttest dengan ranah soal $\mathrm{C} 4$ sampai C6 yang merupakan bagian dari peningkatan keterampilan berpikir kritis siswa. Selain itu, hasil keterampilan berpikir kritis siswa didapatkan dari hasil belajar kognitif siswa yang soalnya mengandung indikator keterampilan berpikir kritis. Dari hasil $\mathrm{N}$-gain dan $t$-test didapatkan kenaikan keterampilan berpikir kritis siswa berkategorikan sedang dan nilai pretest dan posttest terdapat perbedaan. Berdasarkan hasil histogram pada Gambar 1 dapat disimpulkan bahwa rata-rata hasil keterampilan berpikir kritis siswa setiap kegiatan belajarnya mengalami peningkatan. Peningkatan keterampilan berpikir kritis siswa memiliki kategori "baik". Hal tersebut menunjukkan bahwa saat proses pembelajaran siswa berusaha mengembangkan keterampilan berpikir yang mereka miliki dengan mengaitkan antara materi dengan aktivitas eksperimen yang mereka alami. Hal ini sesuai dengan penelitian Ersoy dan Baser (2014) yang menyimpulkan bahwa problem based learning dalam pembelajaran mampu meningkatkan keterampilan berpikir kritis siswa. Selain itu, dari Gambar 1 terlihat bahwa skor terendah pada aspek keterampilan berpikir kritis siswa kelas IX.B adalah keterampilan menentukan strategi dan taktik, hal ini disebabkan sebagian siswa ada yang kurang aktif dalam proses pembelajaran, mereka tidak berdiskusi dengan teman yang lain. Sedangkan skor tertinggi pada kelas IX.B adalah pada keterampilan membangun keterampilan dasar yang di dalamnya meliputi keterampilan mengamati, hampir seluruh siswa melakukan pengamatan dengan baik dan benar.

Setelah dilakukan pembelajaran menggunakan modul berbasis masalah pada materi litosfer, seluruh siswa diberikan angket untuk mengetahui respon dari siswa. Hasil respon siswa diperoleh pada kategori sangat baik. Dari hasil uji coba skala besar, diperoleh saran dan masukan siswa terhadap modul pembelajaran berbasis masalah. Data menunjukkan modul yang digunakan pada uji coba skala besar tidak perlu diperbaiki karena menurut pendapat siswa modul pembelajaran berbasis masalah yang digunakan sudah baik dari segi visual, materi, gambar, keterbacaan, dan soal yang digunakan. Hasil tanggapan siswa terhadap modul sudah baik sehingga tidak perlu dilakukan perbaikan dan layak untuk digunakan, selanjutnya produk modul 
didesiminasi ke sekolah di Kabupaten Wonogiri.

\section{Tahap Diseminasi}

Modul pembelajaran berbasis masalah pada materi litosfer disebarkan ke 5 guru IPA SMP di kabupaten Wonogiri. Penyebaran dilakukan pada guru. Penyebaran dilakukan kepada SMP Negeri 6 Wonogiri, SMP Negeri 2 Selogiri, SMP Negeri 3 Selogiri, dan SMP BP Nawa Kartika. SMP tersebut mempunyai karakteristik sama dengan sekolahan tempat penelitian dan sebagian mempunyai karakteristik di atas sekolah tempat penelitian. Setelah modul pembelajaran berbasis masalah pada materi litosfer dibagikan, guru-guru diberikan angket untuk mengetahui respon guru-guru terhadap modul yang telah dikembangkan. Respon guru-guru terhadap modul pembelajaran berbasis masalah dalam kategori sangat baik. Menurut para guru modul IPA ini dapat melatih siswa belajar secara mandiri dalam memahami konsep materi litosfer yang terkadang guru jarang dapat menjelaskannya. Hal ini sesuai dengan pendapat Anwar (2010), bahwa modul adalah bahan ajar yang disusun secara sistematis dan menarik yang mencakup isi materi, metode dan evaluasi yang dapat digunakan secara mandiri untuk mencapai kompetensi yang diharapkan. Terdapat saran dari guru yaitu untuk menyebarkan modul pada sekolah yang lebih luas lagi dan membuat modul-modul untuk pembelajaran pada materi yang lain.

\section{Kesimpulan dan Rekomendasi}

Kesimpulan yang diperoleh dari penelitian ini antara lain kesimpulan pertama adalah karakteristik modul IPA dikembangkan dengan berbasis masalah pada materi litosfer untuk meningkatkan keterampilan berpikir kritis. Tahapan pembelajaran berbasis masalah yang dimunculkan sebagai kerangka dalam modul meliputi merumuskan masalah, merumuskan hipotesis, mengumpulkan data, menyimpulkan dan menyajikan hasil karya, dan merumuskan rekomendasi pemecahan masalah yang diintegrasikan dengan komponen keterampilan berpikir kritis yang terdapat pada setiap tahapnya yang meliputi memberikan penjelasan sederhana, membangun keterampilan dasar, membuat inferensi, membuat penjelasan lebih lanjut, dan mengatur strategi dan teknik. Modul pembelajaran IPA berbasis masalah untuk meningkatkan keterampilan berpikir kritis siswa dikembangkan berdasarkan format kriteria modul yang diadaptasi dari Sanjaya (2011) dengan model pengembangan modul pembelajaran berbasis masalah pada materi litosfer menggunakan model 4-D yang meliputi tahap define, design, develop, dan disseminate. Kesimpulan kedua adalah modul dikategorikan layak karena telah melalui beberapa uji kelayakan. Modul pembelajaran IPA berbasis masalah untuk meningkatkan keterampilan berpikir kritis siswa divalidasi oleh dosen, guru IPA, dan peer review. Hasil validasi dosen ahli materi pada kelayakan isi dan kelayakan penyajian menunjukkan kategori sangat baik. Hasil validasi ahli bahasa, guru IPA, dan peer review pada kelayakan bahasa menunjukkan pada kategori sangat baik. Hasil validasi dosen ahli media, guru IPA, dan peer review pada kelayakan kegrafikan menunjukkan modul berkategori baik. Modul dikategorikan layak karena telah melalui beberapa uji kelayakan. Berdasarkan hasil uji coba produk awal, uji coba skala kecil, uji coba skala besar, serta diseminasi, keseluruhan penilaian mengenai modul IPA berbasis masalah rata-rata persentase sebesar 90,16\% yang dikategorikan sangat baik. Kesimpulan ketiga adalah pembelajaran menggunakan modul IPA berbasis masalah dapat meningkatkan keterampilan berpikir kritis siswa, hal tersebut dapat dilihat dari nilai pretest-postest siswa kelas IX.B sebelum dan sesudah menggunakan modul pembelajaran IPA berbasis masalah dengan skor rata-rata $N$ Gain sebesar 0,69 dengan kategori sedang. Hasil uji statistik menunjukkan nilai signifikasi lebih rendah dari taraf signifikasi $\alpha=0,05$ (tingkat kepercayaan 95\%) sehingga dapat disimpulkan bahwa modul pembelajaran berbasis masalah efektif untuk meningkatkan keterampilan berpikir kritis siswa. Selain itu, pembelajaran menggunakan modul IPA berbasis masalah dapat meningkatkan hasil 
belajar siswa siswa kelas IX.B, hal tersebut dapat dilihat dari skor rata-rata pretest 53,13 yang berada di bawah KKM dan meningkat pada skor rata-rata postest 86,42 yang mencapai di atas KKM. Hasil belajar afektif dan psikomotor siswa juga mengalami kenaikan menjadi semakin membaik dari pertemuan sebelumnya.

Hasil penelitian ini dapat digunakan sebagai acuan untuk mengembangkan penelitian sejenis, terutama penelitian pengembangan modul dalam pembelajaran IPA. Peneliti dapat mengembangkan modul dengan karakteristik model pembelajaran dan materi yang berbeda. Peneliti harus memahami tentang karakteristik model pembelajaran yang digunakan dan siswa yang dijadikan sampel hendaknya diberikan pemahaman yang jelas tentang pembelajaran berbasis masalah.

\section{Daftar Pustaka}

Anwar, Ilham. (2010). Pengembangan Bahan Ajar. Bahan Kuliah Online. Direktori UPI. Bandung.

Arikunto, Suharsimi. (2010). Prosedur Penelitian Suatu Pendekatan Praktik. Jakarta: PT. Rineke Cipta.

Ennis. (1996). Critical Thinking. Nes Jersey: Prentice Hall. Uper Saddle River.

Ersoy, E dan Baser, N. (2014). The Effects of Problem-based Learning Method in Higher Education on Creative Thinking. World conference on educational sciences. ISSN: 1877-0428, 2014 (hal 3494-3498).

Etherington, Mattew. (2011). Investigative Primary Science: A Problem-based Learning Appoarch. Australian Journal of Teacher Education. Vol 36, 2012 (hal 36-57).

Hartati, Risa. (2015). Meningkatkan Kemampuan Berpikir Kritis Siswa Melalui Implementasi Model Problem Based Learning (PBL) Pada Pembelajaran IPA Terpadu Siswa SMP. ISBN: 978-60219655-8-0, SNIPS 2015 (hal 505-508).

Harahap, Bangun. (2008). Penggunaan Problembased Learning (PBL) Berorientasi Kegiatan Lab untuk Mencapai Kompetensi Fisika. UNIMED. Medan.
Hansen, J.W \& Lovedahl, G.G. (2004). Developing Technology Teachers: Questio-ning The Industrial Tool Use Model. Journal of Tehnology Education. 15 (2) 20-32.

Ibrahim, Badafal. (2005). Dasar-dasar Manajemen dan Supervisi Taman Kanak-Kanak. Jakarta: PT Bumi Aksara.

La Iru dan La Ode Safiun Arihi. (2012). Analisis Penerapan Pendekatan, Metode, Strategi, dan Model-Model Pembelajaran. DIY: Multi Presindo.

Liliasari dan Tawil. (2013). Berpikir Kompleks dan Implementasinya dalam Pembelajaran IPA. Makasar: Badan Penerbit UNM..

Mullis, I.V.S., Martin, M.O., dan Foy, P. (2007). TIMSS 2007 International Mathematics Report Findings From IEA's Trends in International Mathematics and Science Study at The Fourth and Eighth Grades. Chestnut Hill, MA: TIMSS \& PIRLS International Study Center, Boston College.

PISA. (2012). Snapshot of Performance in Mathematics, Reading, and Science. Diunduh 15 Januari 2015.

Thiagarajan, Sivasailam, DS, Semmel Melvyn. (1974). Instruction Development for Training Teachers of Exceptional children. Minneapolis: Indian University.

TIMSS. 2007. Hasil TIMSS Matematika SMP/MTs Kelas VIII. Diunduh 15 Januari 2015.

Sanjaya, W. 2011. Perencanaan dan Design Sistem Pembelajaran. Jakarta: Media Group. 


\section{JURNAL INKUIRI}

ISSN: 2252-7893, Vol. 6, No. 3, 2017 (hal 141-152)

http://jurnal.uns.ac.id/inkuiri 